\section{The Influence Of Folk Riddles On The Creation Of Literary Riddles}

\author{
Rano Zaripovna Rajabova, \\ Independent Researcher, Department Of Uzbek Literature, \\ Bukhara State University, Uzbekistan
}

\section{G OPEN ACCESS \\ The American Journal of Social Science And Education Innovations JULY 2020 \\ Page No.: 278-284 \\ Volume-II Issue-VII \\ PUBLISHED: 30 JULY 2020 \\ www.usajournalshub.com/inde x.php/tajssei \\ Copyright: Original content from this work may be used under the terms of the Creative Commons Attribution 4.0 licence.}

\title{
Abstract
}

Literary riddles are mainly based on creativity in poetic form, poetic analogy, comparison, contrast, and conditional migration. Although a literary riddle is created in the structure and style of a folk riddle, it is considered a literary riddle because it is creatively created by a particular poet. They are distinguished by their rhythmic sequence, artistic melody, abundance and variety of rhymes.

The article discusses the creation of literary images for children based on the subsequent direct stylization of the riddle, one of the most ancient, popular, traditional paremic genres of folklore, their similarities and differences with folk riddles. Literary puzzles, like folk riddles, are very rich and diverse in subject. These include natural phenomena, the moon and the seasons, the earth and celestial bodies, bodies of water, mountains, flora and fauna, human organs, fruits and vegetables, melons, household items and instruments, instruments, musical instruments, modern technology, teaching aids, types of food. Literary puzzles, like folk puzzles, entered our lives as a result of the development of science, technology and culture, both in the past and in the present.

Keywords: folklore, riddle, literary riddle, stylization, metaphor, animation, analogy, 
adjective, rhetoric, metonymy.

\section{Introduction}

Given the uniqueness of the role and influence of folklore in the development of the younger generation in the spirit of devotion to national traditions, special attention is paid to their education.

In the works of folklore, the lofty aspirations of our people, their courageous struggle for freedom and liberty have found their artistic expression. In particular, the brilliant and rich songs created by the intellect of our ancestors, interesting legends, stories, tales and epics from the events of the past, wise and instructive proverbs, ingenuity, mind-boggling riddles, speech-enhancing rhetoric, laughter anecdotes, lofts are valuable in that they serve to strengthen feelings of patriotism and nationalism in every heart.

The riddles, created over the centuries on the basis of the people's beliefs and passed down from generation to generation, are still a tool in educating young people on the basis of national spiritual values. Through the study of written riddles, it is possible to reveal the interaction of folklore and written literature, their interaction, on this basis, the features and principles of the gradual development of poetic thought.

\section{The Main Part}

Riddle, which is a unique form of artistic perception of life, is one of the most popular genres of Uzbek folklore. Man and the world around him are reflected in riddles in a unique poetic form through movements, analogies, comparisons, comparisons, comparisons, questions. In this respect, it is an extraordinary event in the development of human artistic thought, in which the figuratively expressed piece of life is realized through the answers to the riddle. Such a common feature, peculiar to the poetic nature of the genre, applies to the riddles of all peoples. So it is an international genre. At the same time, the riddle of each nation is unique, original, attractive and unique as an expression of the way of life of that nation.

A puzzle or task given in a poetic or prose structure is a puzzle made up of two objects, things, and events that are similar in form, function, action, and situation, and intended to find it on the basis of similar features specific to the other. Take, for example, the riddle "Bir parcha patir, Olamga tatir." In this case, the full moon and the patir were 
compared and it was found that they were similar in form. Thus the answer to the riddle a very beautiful and appropriate movement of the moon - was found. Considering that the patriarch is an extremely nutritious food for man, and that the moon illuminates the dark night, both of which are aimed at humanity, it is also clear that there is a great spiritual closeness between them. The term "Riddle" was formed by adding the suffix "top" to the command verb "top", and the genre term was formed by adding the form "moq" to it.

Riddles are also represented by different words in different districts of the republic, such as riddles, jumboq, jummoq, jumoq, topcha, topar cho'pchak, top-top, top-top cho'pchak, matal, masala, ushuk. But now, "riddle" has been fully mastered as a single scientific and literary term, and the rest has been used in narrow circles and in the speech of some older people.

Uzbek folk riddles are thematically rich and colorful. There is no sphere of social life of our people, the nature, geography, ecology, flora and fauna, man and the universe, about which there are no beautiful, very concise and concise riddles. Earth and sky, rivers and lakes, mountains and rocks, trees and forests, orchards and vast fields, household appliances and tools of labor, thunder and lightning, floods and storms, darkness and light, moon and seasons, animals and plants the world, teaching aids and musical instruments, modern technology and technical means, many riddles about man and the environment around him have been woven and passed down from generation to generation to the present day. The puzzles reflected the daily life, behavior and way of life, beliefs, imagination and worldview of the people.

A question or task in a poetic or prose structure is a "riddle" in which two objects, things, and events that are similar in form, function, action, and state are puzzled to find it on the basis of a similar poetic or prose structure referred [1].

The riddle is present in the folklore of all nations, including the Uzbek folklore. Lyrical genres such as lug'z, chiston, muammo, muvashshah, ta'rix emerged and achieved artistic perfection on the basis of the direct stylization of the riddle genre, one of the oldest, most popular, traditional paremic genres of folklore, later in written literature. From the second half of the last century, the experience of creating literary puzzles in children's poetry was formed and gradually developed. The riddles arose on the basis of a 
conditionally secret speech, the ground of which is connected with the ancient beliefs and imaginations of the people, their level of knowledge and understanding of the world.

Alisher Navoi's dictionaries and Uvaysi's poems are also very popular in our classical poetry. They were created in a dream weight. The tradition of creating literary riddles is also found in the sayings of Makhtumkuli and Durdi Kilich. By the twentieth century, the creation of literary puzzles in the form of a poem, in the weight of a finger, in simple language, in a concise form, close to the oral riddle, became widespread. In this regard, the riddles created by such poets as G.Gulam, K.Muhammadi, Sh.Sa'dulla, S.Gafurov, P.Mumin, K.Turdieva, N.Ermat, M.Sayfiddinova enriched the treasury of children's literature.

Indeed, Z. Husainova writes: "In the past, nature and natural phenomena themselves were a mystery that people did not know and could not solve, their mysteries seemed like a miracle ... When a person begins to recognize the external objective world around him, what is in it and began to study by comparing, comparing, and sometimes contrasting things and events in the desire to know, to understand how events are created. They did not fully understand the essence of the movement of the sun, moon, stars, lightning, blue thunder, clouds, wind, snow and rain, and based on animistic concepts, imagined that they all had a soul. Some manifestations of such concepts are also found in riddles. In the riddle "One father, one mother, hundreds of thousands of children," the comparison of the sun, moon, and stars to man and their animation is related to primitive concepts. Because man has not yet fully understood nature and its mysteries, and at a time when totemistic concepts prevailed, he imagined the sun and the moon as the beginnings of fatherhood and motherhood - father and mother "[2]. So, riddles have gone through a complex path of development, from the time when they once performed certain magical functions, to the time when they became a means of intelligence, a race of intelligence, a means of entertainment, a means of entertainment. That is why they are diverse in terms of the nature, structure, and artistic features of depicting life. They have retained the traces of time, the people's aesthetic taste, emotional feelings have increased, their mythological ideas and ancient notions have diminished. Poetic pressure began to come to the fore. As a result, the puzzle has lost its 
connection with various ceremonies and other everyday functions and has become a genre that serves a purely artistic-aesthetic function.

According to the folklorist $\mathbf{Z}$. Husainova, in the execution of the riddle there were strict traditions, specific rules, certain prohibitions [3]. At least two people are required to complete the riddle - the one who tells the riddle and the one who finds the answer.

\section{Results and Discussions}

In the past, if the answer to the riddle was not found, the "city" was given by the solver. The performance of "Taking the City" served to embarrass and humiliate the person who could not find the riddle [1]. Only then did the narrator themselves say the answer to the riddle. Saying a riddle without knowing the answer is strongly condemned.

Knowing this, some poets began their literary riddles by warning children through introductory verses, such as fairy tales. For example, Polat Momin quotes the following verses before bringing them to the children's attention:

Quloq solib tur o'rtoq,

Aytay senga topishmoq.

Eshitgach, biroz to'xta!

O'ylab olgin-da puxta,

Keyin qo'lingni ko'tar,

Bo'Imasa galing o'tar.

Topganiga yarasha,

Har kimga deyman, yasha!.

(Listen to me, comrade,

Let me tell you a riddle.

Stop for a moment when you hear that!

Think carefully,

Then raise your hand,

Otherwise, the bride will pass.

As you can see,

I say to everyone, live! ) [4].

As one of the ancient genres of folklore, the Greek philosopher Aristotle [5] and the 
English scholars E.B. Taylor [6], J.J. Fraser, Uzbek scientists Z.Husainova, M.Juraeva.

There are riddles that will be answered as soon as they are told. But there are also riddles that are so hard to find an answer that even people with great life experience will ponder. Therefore, additional information is provided to make it easier to find the answer to the riddle.

Literary riddles have a special place among children's poetry, as they are mainly created in poetic form, based on poetic analogy and comparison, contrast, conditional migration, concise in structure, internal and external rhyme, manifested as a wide-ranging poem. Although they are created in the structure and style of folk riddles, they are considered literary riddles because they are created creatively by a particular poet. They are distinguished by their rhythmic consistency, artistic melody, abundance and variety of rhymes. The means of artistic representation and migration, such as metaphor, metonymy, rhetoric, simile, adjective, provide the art in them. The variety of alliteration and repetition further enhances the emotional sensitivity of literary puzzles.

Most literary puzzles are created for educational purposes. Through them, first of all, it is intended to expand the scope of children's thinking, increase their observation and ingenuity, intelligence, develop the ability to think logically.

Literary riddles, like folk riddles, are about things from the past, as well as things that have come into our lives (such as computers and cell phones) as a result of the development of science, technology and culture today.

It is known that before independence, riddles about trams, gramophones, samovars, records were presented as "new riddles" among folk riddles. But it's hard to say that all of today's kids have seen and known them.

The riddles are distinguished by their rhythmic consistency, artistic melody, abundance and variety of rhymes. The means of artistic representation and migration, such as metaphor, metonymy, rhetoric, simile, adjective, provide the art in them. The variety and variety of alliteration and repetition further enhanced the resonance and emotional impact of the riddles. All of this combined to ensure that they remain in human memory for a long time.

\section{Conclusion}


Although literary riddles are created in the structure and style of folk riddles, they are considered literary riddles because they are creatively created by a particular poet. They are distinguished by their rhythmic consistency, artistic melody, abundance and variety of rhymes. The puzzles had a blessed influence on the development of literature and art. They have played an important role in the history of our literature in the emergence and development of lyrical genres such as chiston, problem, muvashshah, ta'rix. Today, riddles have a great enlightenment and educational value. They are an important aesthetic tool for broadening the horizons of our children and youth, increasing their ingenuity and developing their ability to discuss.

\section{References}

1. Aristotle. Poetics. Tashkent, 1980. 45 p.

2. Husainova Z. Riddles // Essays on Uzbek folklore. Three volumes, the first vol. --T.: 1988. - P. 100-101.

3. Husainova 3. Uzbek riddles. - T .: Fan, 1966. - P.14.

4. Ermat N. 99 Accelerations and Riddles [Text]. - Tashkent: "Muharrir" publishing house, 2019. - P.46.

5. Polat Momin. The sun came out into the world. Poems, songs, tales and riddles. - T .: Uzdavnashr, 105 p. - P.162.

6. Rajabova R.Z. A literary riddle from a folk riddle. European Scientific Conference: collection of articles of the XXI International Scientific and Practical Conference. - M: ICNS "Science and Education". - 2020.- 318 p.

7. Rustamova G.B. The interpretation of the willow image in uzbek folklore Asian Journal of Multidimensional Research (AJMR) ISSN: 2278-4853 Impact Factor: SJIF $2020=6.882$ Vol 9, Issue 4, April, 2020 Spl Issue. DOI NUM: 10.5958/2278-4853.2020.00086.5. - P. 21-27.

8. Safarov O. Uzbek folk oral art. Textbook. - T .: Musiqachi, 2010. - P. 382.

9. Taylor E.B. Primitive culture. M., 1989. - P. 78-511.

10. Ismatullayeva N.R. The Concept of "Lacuna" in Translation Studies. Asian Journal of Multidimensional Research (AJMR). ISSN: 2278-4853, Volume-9, Issue-4, April 2020. - pp 123-129. DOI: $10.5958 / 2278-4853.2020 .00103 .2$ 